\title{
PENGARUH KONSENTRASI ZPT ALAMI DAN SINTETIK TERHADAP PERTUMBUHAN DAN HASIL TANAMAN KEDELAI (Glycine max L. Merril)
}

\author{
Oleh *Susanti** Kesumawati(2) dan **Oktavidiati (*alumni FP UMB dan \\ **Dosen FP UMB)
}

\begin{abstract}
Di Provinsi Bengkulu peningkatan hasil produksi kedelai disebabkan karena adanya pertambahan luas lahan, akan tetapi hasil produksinya masih belum mencukupi untuk memenuhi kebutuhan di provinsi itu sendiri. Hal ini bertujuan untuk mengetahui pengaruh konsentrasi zpt alam dan sintetik terhadap pertumbuhan dan hasil kedelai (Glycine max) L.Merril). Penelitian ini dilakukan di J1. Danau Raya No.59, Panorama, Singaran Pati, Kota Bengkulu pada ketinggian $24 \pm$ mdpl menggunakan Rancangan Acak Lengkap faktorial dengan 2 faktor. Faktor pertama pemberian Auksin Alami (A): A1 25 ml, A2 50 ml, A3 75 ml. Faktor kedua adalah auksin sintetik (B): B0 (Kontrol) B1 (1 ml) B2 (1,5 mon 1) dan B3 (2 ml), masing-masing perlakuan dilakukan sebanyak 3 kali. Analisis data menggunakan Analysis of Variance Analysis (ANOVA). Hasil yang berbeda diikuti oleh Duncan Multiple Range Test (DMRT) level 5\%.

Hasil perlakuan auksin alami berpengaruh sangat nyata terhadap jumlah daun 14 HST, bobot basah tanaman, bobot kering tanaman, bobot 100 biji kadar air kedelai $14 \%$ sedangkan pengaruh signifikan terjadi pada tinggi tanaman 56 HST, jumlah Jumlah cabang 28 HST, jumlah cabang 42 HST kedelai (Glycine max L. Merril). Sedangkan pemberian auksin sintetik berpengaruh nyata terhadap panjang akar dan berpengaruh nyata terhadap tinggi tanaman 14 HST kedelai (Glycine max L. Merril). Dalam penelitian ini, tujuan interaksi antara auksin alam dan auksin sintetik terjadi pada panjang akar tanaman kedelai.
\end{abstract}

Kata kunci: Kedelai, auksin alam, auksin sintetik.

\begin{abstract}
In Bengkulu province the increase in soybean production results is due to an increase in land area, but the production results were still not sufficient to meet the needs in the province itself. It aims to determine the effect of of natural and synthetic zpt concentrations on the growth and yield of soybean (Glycine max) L.Merril). This research was conducted on J1. Danau Raya No.59, Panorama, Singaran Pati, Bengkulu City at an altitude of $24 \pm$ masl using a factorial Completely Randomized Design with 2 factors. The first factor giving Natural Auxin (A): A1 $25 \mathrm{ml}, \mathrm{A} 250 \mathrm{ml}, \mathrm{A} 375 \mathrm{ml}$. The second factor is synthetic auxin (B): B0 (Control) B1 (1 ml) B2 (1.5 mon l) and B3 (2 ml), each treatment was done for 3 times. The data was analyzed using Analysis of Variance Analysis
\end{abstract}


(ANOVA). The different results were followed by Duncan's Multiple Range Test (DMRT) level of 5\%. The results of natural auxin treatment have a very significant effect on the number of leaves of 14 HST, plant wet weight, plant dry weight, weight of 100 seeds water content of $14 \%$ soybeans while significant effect occurs on plant height of 56 HST, number of branches 28 HST, number of branches 42 HST soybean (Glycine max L. Merril). While the provision of synthetic auxin which significantly affected root length and significantly affected plant height of 14 HST, soybean (Glycine max L. Merril). In this research, the aim of the interaction between natural auxin and synthetic auxin occurs in the root length of soybean plants.

Key words: Soybean, natural auxin, synthetic auxin. 


\section{BAB I \\ PENDAHULUAN}

Kedelai (Glycine $\max \mathrm{L}$. Merril) merupakan salah satu tanaman multiguna karena dapat digunakan sebagai pangan, pakan, maupun bahan baku industri (Sudaryanto dan Swastika 2007). Pemanfaatan kedelai Indonesia $\pm 94 \%$ digunakan untuk pembuatan bahan pangan, seperti tempe, oncom, tauco, kecap, dll (Swastika, Marwanto dan Simatupang 2005). Bahan pangan tersebut angat digemari masyarakat karena memiliki kandungan gizi yang sangat bermanfaat bagi kesehatan tubuh manusia. Menurut Amanda (2008), kandungan gizi dari $100 \mathrm{~g}$ kedelai adalah 330 kal kalori, $35 \mathrm{~g}$ protein, 18 glemak, $35 \mathrm{~g}$ karbohidrat, 8 g air, $227 \mathrm{mg}$ kalsium, $585 \mathrm{mg}$ fosfor, $8 \mathrm{~g}$ besi, vitamin A dan vitamin B1.

Badan pusat Statistik di Bengkulu menyatakan bahwa penduduk di Bengkulu mengalami peningkatan pada tahun 2016 yaitu 359.488 jiwa dan pada tahun 2017 yaitu 368.065 jiwa. Pada tahun 2017 naik 2,33\% di bandingkan tahun 2016 . Peningkatan itu terjadi sebanyak 8,577 jiwa sehingga kebutuhan kedelai pun meningkat seiring bertambahnya jumlah penduduk, kebutuhan akan kedelai terus meningkat namaun produksi kedelai dari luar kota Bengkulu seperti Jawa dan Lampung demi mencukupi kebutuhan kedelai di Bengkulu. https://bengkulukota.bps.go.id/,(2017). Berdasarkan data yang diperoleh di BPS (2017), Jumlah produksi kedelai secara nasional pada tahun 2017 sebanyak 538.728 ton, sangat jauh sekali mengalami penurunan dari tahun sebelumnya (2016) yaitu sebanyak 859.653 ton.
Begitu juga yang dialami provingsi Bengkulu sangat jauh drastic mengalami penurunan. Dari tahun 2016 produksi di Bengkulu sebanyak 4.664 ton, di tahun 2017 produksi kedelai di Bengkulu hanya mencapai 413 ton (http:/antarabengkulu.com, 2015). Untuk dapat memenuhi kebutuhan kedelai, Bengkulu mengandalkan impor dari luar provinsi seperti provinsi Lampung dan Jawa yang dimana provinsi Lampung dan Jawa lebih besar dari Bengkulu, yakni sebanyak 9.960 ton. (BPS, 2016).

Zat pengatur tumbuh merupakan sekumpulan senyawa organik atau hormon tumbuh yang memiliki daya ransangan terhadap tanaman. Zat pengatur tumbuh biasanya yang tercipta secara endogen oleh tanaman itu sendiri maupun secara eksogen yang di bentuk oleh manusia dalam bentuk sintetis, zat pengatur tumbuh terdiri atas gologan auksin dan sitokinin (lestari, 2012). Zat pengatur tumbuh merupakan senyawa yang dalam kosentrasi rendah dapat memacu pertumbuhan tanaman zat pengatur tumbuh yang di tambahkan dapat memanipulasi pertumbuhan dan perkembangan tanaman yang mengaruh pada peningkatan kualitas dan kuantitas benih kedelai, pembesaran ukuran biji dan memperbaiki kandugan gizi seperti lemak dan protein ( Podesta, dkk. 1997 Diikutif Mareza, 2009). ZPT untuk memacu terbentuknya perakaran, tunas, cabang, daun bunga dan buah. Ada berapa macam dalam tumbuhan mengandung zat alami yaitu salah satunya air kelapa dan berapa jenis tanaman lain nya. Pemberian zat perangsang tumbuh (ZPT) yang dapat merangsang pertumbuhan akar dapat dilakukan. 
Banyak bukti menyatakan bahwa auksin berpengaruh terhadap pertumbuhan batang dan akar (Artanti,2007).

Air kelapa (Cocos nucifera) mengandung zat pengatur tumbuh auksin dan sitokinin. Auksin dapat merangsang pertumbuhan dengan cara pemanjangan sel dan menyebabkan dominasi ujung, Di dalam air kelapa juga terdapat zat pembangun lainya seperti protein, lemak, mineral, karbohidrat bahkan lengkap dengan vitamin C dan B kompelks ( Susilo, 1996). Hasil penelitian yang sudah di teliti pada tanaman komoditi lain MELATI PUTIH (jasminum sambac 1). Menyatakan hormon dalam air kelapa yang sudah di ketahui adalah auksin mencapai $60 \%$ dan sitokinin mencapai $20 \%$.

Dalam dunia pertanian, penggunaan ZPT merupakan faktor pendukung yang dapat memberikan kontribusi besar dalam keberhasilan usaha budidaya pertanian. Namun penggunaan ini harus dilakukan dengan tepat karena tingkat keberhasilan dalam penggunaan ini sangat bergantung pada jenis yang digunakan. Biasanya penggunaan ZPT dengan kadar rendah akan menghambat pertumbuhan, meracuni, bahkam menimbulkan kematian pada tanaman Selain jenis auksin, keberhasilan penggunaan auksin sintetik juga dipengaruhi oleh konsentrasi auksin, contohnya konsentrasi penggunaan ZPT auksin sintetik golongan NAA (Napthalene Acetic acid) yang dianjurkan adalah 1$3 \mathrm{ml} / \mathrm{l}$ air (Fatma, 2009 dan Dwi, 2015).

Seiring dengan kemajuan pengetauan dan teknologi tentang biokimia,saat ini telah ditemukan beberapa senyawa yang memiliki fungsi fisologis serupa dengan hormon tubuhan. Sumber ZPT sitokinin alami pada tanaman kacang kedelai adalah air kelapa. Selama ini air banyak dimanfaatkan untuk minuman kesegaran, air kelapa mengandung berbagai macam zat, termasuk di dalamnya hormon sitokinn dan auksin. Benzil Amino purin merupakan salah satu jenis zat pengatur tumbuh sintetik golongan NAA yang sering di gunakan dalam pertumbuhan tanaman.

Adapun aukin sintetik yang gunakan yaitu golongan auksin NAA (Napthalene Acetic acid). NAA ini telah terbukti untuk meningkatkan pembentukan serat selulosa pada tanaman ketika di kombinasikan dengan hormon tumbuhan lain yang di sebut asam giberelin. Auksin ini telah di pahami untuk mencegah pematangan buah sebelum waktunya dan penipisan buah-buahan dari batang . NAA ini telah banyak di gunakan pada tanaman yang berbeda-beda termasuk apel dan lain-lain, dalam rangka untuk mendapatkan efek yang di inginkan harus diterapkan dalam kosentrasi mulai $1-2 \mathrm{~g} / \mathrm{ml}$

Berdasarkan latar belakang yang telah di uraikan di atas perlu di lakukan penelitian tentang " Pengaruh kosentrasi zat pengatur tumbuh alami dan sintetik terhadap Pertumbuhan Dan Hasil Tanaman Kedelai (Glycine max (L) Merril ).

\section{BAB II \\ METODOLOGI PENELITIAN}

\subsection{Waktu dan Tempat Penelitian}

Penelitian ini dilaksanakan dilahan petani JL. Danau Raya No.59, Panorama, Singaran Pati, Kota 
Bengkulu pada ketinggian tempat 24 meter di atas permukaan laut, dilaksanakan, pada bulan November 2019 sampai Februari 2020.

\subsection{Bahan dan Alat}

Alat yang digunakan yaitu; cangkul, jarum suntik, timbangan besar, sprayer, ember, gayung, , mistar, kamera, dan alat tulis.

Bahan yang digunakan yaitu; Rhizobium, polibag ukuran $10 \mathrm{~kg}$. benih kedelai varietas Dena-1 di peroleh dari Balai Kacang-kacangan dan Umbi-umbian Malang, auksin sintetik (NAA) dan auksin alami (air kelapa).

\subsection{Rancangan Penelitian}

Penelitian ini di laksanakan dengan menggunakan Rancangan Acak Lengkap (RAL) disusun secara faktorial. Terdiri dari 2 faktor yaitu; Faktor pertama adalah pemberian Auksin Alami (A) yaitu:

$\mathrm{A} 1=$ Air kelapa $25 \mathrm{ml} / 1$ air
A2 = Air kelapa $50 \mathrm{ml} / 1$ air

A3 = Air kelapa $75 \mathrm{ml} / 1$ air

Faktor kedua

pemberian

Auksin Sintetik (B) yaitu:

B0 $=$ Kontrol (Tanpa auksin sintetik)

$\mathrm{B} 1=$ Auksin NAA $1 \mathrm{ml} / 1$ air

$\mathrm{B} 2=$ Auksin NAA 1,5 ml/1 air

B3 = Auksin NAA 2 ml/1 air

Dari perlakuan ini terdapat 12 kombinasi perlakuan yang di ulang sebanyak 3 kali ulangan sehingga terdapat 36 kombinasi perlakuan sehinga setiap satuan percobaan terdapat 3 tanaman sehingga di peroleh 108 unit tanaman.

\section{BAB III \\ HASIL DAN PEMBAHASAN}

\subsection{Hasil}

Hasil analisis keragaman untuk masing-masing faktor dan interaksinya terhadap semua peubah yang diamati dalam penelitian dapat dilihat pada tabel 2 dibawah ini.

Tabel 2. Ringkasan hasil analisis ragam pada semua peubah pengamatan pertumbuhan dan hasil tanaman kedelai (Glycine max L. Merril).

\begin{tabular}{lcccc}
\hline \multicolumn{1}{c}{ Peubah pengamatan } & \multicolumn{3}{c}{ F-hitung } & KK \\
\cline { 2 - 4 } & $\mathrm{A}$ & $\mathrm{B}$ & $\mathrm{AB}$ & \\
\hline Tinggi tanaman 56 hst (cm) & 0.82 & $3.38 *$ & $4.20 * *$ & 10.24 \\
Jumlah daun 56 hst (helai) & 0.81 & 1.37 & $5.52^{* *}$ & 9.95 \\
Jumlah cabang 56 hst (Cabang) & 1.90 & 0.85 & $3.42^{*}$ & 13.53 \\
Berat basah tanaman (gr) & $4.46 *$ & 1.26 & 1.51 & 10.95 \\
Berat kering tanaman (gr) & $3.75 *$ & 0.71 & 2.09 & 15.06 \\
Berat polong cipo (gr) & 0.32 & 0.19 & 0.99 & 6.02 \\
Jumlah polong (gr) & 1.24 & 1.22 & 0.91 & 6.26 \\
Jumlah polong cipo (gr) & $9.28 * *$ & $8.83 * *$ & 3.54 & 12.85 \\
Berat 100 biji (gr) & $10.69 * *$ & 0.76 & 1.88 & 5.83 \\
Panjang akar (cm) & 2.99 & $4.77 *$ & $3.86 *$ & 7.99 \\
Jumlah bintil akar (gr) & 0.98 & 3.32 & 2.36 & 10.71 \\
\hline
\end{tabular}




$\begin{array}{cl}\text { Keterangan } & : \\ \text { A } & : \text { Pemberian Auksin Alami } \\ \text { B } & : \text { Pemberian Auksin Sintetik } \\ \text { AB } & : \text { Interakasi } \\ \text { tn } & : \text { Tidak Berpengaruh Nyata } \\ * & : \text { Berpengaru nyata } \\ * * & : \text { Sangat Berpengaruh Nyata } \\ \text { KK } & : \text { Koenfisien Keragaman }\end{array}$

\subsection{Pembahasan}

Pengaruh konsentrasi zpt alami dan sintetik terhadap pertumbuhan dan hasil tanaman kedelai (Glycine max L. Merril).

Hasil penelitian menujukan bahwa perlakuan kosentrasi zat pengatur tumbuh alami telah menujukan pengaruh yang sangat nyata terhadap jumlah daun 14 HST, jumlah cabang 28 HST, Jumlah cabang 42 HST, berat basah tanaman, berat kering tanaman, jumlah polong cipo, berat 100 biji. Sedangkan yang tidak memberikan pengaruh nyata pada auksin alami terdapat pada tanaman tinggi tanaman $14 \mathrm{HST}$, tinggi tanaman 28 HST, tinggi tanaman 42 HST, tinggi tanaman 56 HST, jumlah daun 28 HST, jumlah daun 42 HST, jumlah daun 56 HST, jumlah cabanag 56 HST, berat polong cipo, jumlah polong, panjang akar dan jumlah bintil akar hasil ini sejalan dengan penelitian Hilman dan Nurtika,(1992).

Sedangkan pemberian auksin sintetik yang telah menujukan pengaruh nyata terdapat pada tinggi tanaman 14 HST, tinggi tanaman 56 HST, jumlah polong cipo, dan panjang akar, sedangkan yang tidak memberikan pengaruh nyata terdapat pada tinggi tanaman 28 HST, tinggi tanaman 42 HST, jumlah daun 14 HST, Jumlah daun 28 HST, jumlah daun 42
HST, jumlah daun 56 HST, jumlah cabang 28 HST,jumlah cabang 42 HST, jumlah cabang 56 HST, Berat basah tanaman,berat kering tanaman, berat polong cipo, jumlah polong, berat 100 biji, jumlah bintil akar.

Dari penjelasan diatas auksin alami (A) memiliki nilai terbaik hal itu dapat di duga karna adanya bakteri dan mikoorganisme yang terkandung di dalam air kelapa tersebut adalah kalori $17,0 \mathrm{kal}$, protein $0,20 \mathrm{~g}$, lemak 1,00 g, karbohidrat 3,800 g, kalsium 14,11 g, fosfor $13,17 \mathrm{~g}$, besi $0,20 \mathrm{~g}$, air, 95,50 g, dan bagian yang dapat dimakan $100 \mathrm{~g}$ (Kholidin dkk 2016). Fosfor berfungsi dalam reaksi pada fotosintesis, respirasi, untuk merangsang pertumbuhan dan penyuburan akar dan tumbuh kuat sehingga tamanan akan tahan lama kekeringan, kalium (K) dapat merangsang pertumbuhan dengan cepat, aktifator,enzim,mengatur tekanan turgor dalam proses membukak dan menutup stomata, sulfur (S) yang ada dalam air kelapa komponen penyusun asaam amino yaitu metionin, ( Setiawati dkk, 2010) Adapun bakteri yang terkandung di dalam air kelapa yaitu Acetobacetr xylinum (Watanabe,1997) dan didukung dari analisis air kelapa dan tanah, dengan demikian diduga mampu memberikan unsur hara yang tersedia dan dapat diserap dengan tanaman kedelai. 
Pada peubah tinggi tanaman 56 HST menujukan bahwa pemberian B1 (1 ml) berbeda dengan pemberian $\mathrm{B} 0$ (Kontrol) tetapi tidak berbeda nyata dengan perlakuan $\mathrm{B} 2(1,5 \mathrm{ml})$ tetapi berbedanyata dengan B3 (2 $\mathrm{ml})$. seperti pada penelitian yang dilakuakan oleh (Nasution, 2013).

Terjadi Interaksi antara pemberian auksin alami dan auksin sintetik terhadap panjang akar, tinggi tanaman 56 HST, tinggi tanaman 14 HST, jumlah daun 14 HST, jumlah daun 56 HST Jumlah cabang 56 HST, proses pembentukan panjang akar berkaitan dengan adanya auksin alami atau zat perangsang tumbuh yang terdapat pada auksin alami (A) serta kandunga unsur hara yang terdapat dalam auksin alami diduga mendukung dalam proses pertumbuhan tanaman sehinga perlakuan antara keduanya saling menguatkan dan saling berkaitan terhadap panjang akar, tinggi tanaman dan jumlah daun kedelai. Hal ini sependapat dengan Hapiza (2014), menujukan bahwa didalam auksin alami terdapat unsur hara nitrogen sebesar $0,34 \%$ meningkat menjadi $0,89 \%$ setelah difrementasikan. Kandugan unsur $\mathrm{N}$ yang terurai oleh mikroorganisme dan diubah menjadi senyawa amonium dan nitrat yang dapat di manfaatkan oleh tanaman sebagai nutrisi untuk pertumbuhan tanaman terlebih hormone alami yang terdapat dalam auksin berperan dalam proses pertumbuhan akar.

Hal ini di perjelaskan oleh sari, dkk. (2015) bahwa dalam air kelapa terdapat kandungan hormone zat pengatur tumbuh alami yang tergolong dalam auksin yaitu indole Acetic Acid (IAA). Salah satu peran IAA pada tanaman adalah sebagai hormone kunci dari berbagai aspek pertumbuhan dan perkembangan suatu tanman sehingga dapat merangsang dalam proses perbentukan bunga serta buah. Dilihat dari kandungan yang terdapat dalam air kelapa dan auksin sintetik (NAA) diduga bahwa perlakukan tersebut saling berkaitan dan mendukung dalam proses pembentukan bunga serta buah dalam tanman kedelai.

\section{DAFTAR PUSTAKA}

AAK. 2000. Kedelai. Yogyakarta.Hal. 11-23.

Adisarwanto. 2008. Budidaya kedelai Tropika.Penebar Swadaya. Jakarta. Hal. Hal.7-14.

Adisarwanto. 2014. Kedelai Tropika Produktivitas 3 Ton/ha. Penebar Swadaya. Hal.28

Adisarwanto. 2014. Budidaya kedelai Tropika.Penebar Swadaya. Jakarta. Hal. 5-25.

Amanda, Rianti. 2008. Meraup untung dengan palawija. Pringgndani. Bandung.

Anonim,2004. http://www.croplangene tics.com/soybean.asp?topic $=4$ $\underline{\& s m}=$ i_e Akses tanggal 20 Juli 2018.

Chayono, B.2017. Kedelai teknik Budidaya Dan Analisis Usaha tani. Aneka Ilmu. Semarang.

BPS. Badan Pusat Statistik 2017. Jumlah produksi kedelai secara nasional. Statistik Provinsi Bengkulu No. 39/07/17/X, 2017.

Dwi lina, 2015.' Pengaruh konsentrasi zat pengatur tumbuh auksin 
golongan NAA dan waktu penyiangan terhadap pertumbuhan dan hasil kacang hijau ( Vigna Radiata 1.)

Hapiza M.R.,Sabrina T,. Marbun P. 2014. Pengaruh pemberian limbah Cair Industri Tempe dan Mikoriza Terhadap Ketersediaan hara $N$ dan $P$ Serta Produksi jagung (Zea mays L.) pad Tanah inseptisol. Jurnal online Agroteknologi. Volume 2. No. 3. Hal. 10981106. Program Studi Agroteknologi. Fakultas Pertanian. Universitas Sumatra Utara.

Hilman, Y dan N. Nurtika. 1992.pengaruh pupuk kandang terhadap pertumbuhan dan produksi tomat. Bulletin penelitian Hortikultural VolXX11 (1);96-101.

Khair, H.N dan S SYAHD. 2012. Pengaruh kosentrasi ekstra bawang merah dan air kelapa terhadap pertumbuhan stek tanaman melati putih (jasminum sambac L). Jurnal agrium. 18(2):130-138.

Menurut Badan Pusat Statistik (2017), data produksi kacang kedelai'Bengkulu.

Nasution hakiki, Rosmayanti dan Husni. Jurnal penelitian respon pertumbuhan dan produksi kedelai (Glycine max L .merril) yang di beri fungsi mikoriza arbuskular FMApada tanah salin. Medan, volume 2. Nomor 1 :421-427.Desember 2013
Nurlaeni, Y. dan Surya M. I, 2015 . Respon Stek Pucuk Camelia japonica terhadap pemberian Zat pengatur Tumbuh Organik . Prosiding seminar Nasional Masyarakat Biodiversifikasi indonesia. Volume 1 nomor 5 Agustus 2015 .

Kristina, N. N dan S F Syahid. 2012. Pengaruh Air Kelapa Terhadap Multiplikasi Tunas In Vitro, Produksi Rimpang dan Kandungan Xanthorrhizol Temulawak Di Lapangan. Jurnal Littri 18(3), 125-134.

Padjar. M. 2010. Varietas kedelai. http:/dedenia

Wordpress.com/2009/09/002/ Varietas-kedelai-soybean-part1/html. [13 September 2014].

Padjar. 2010. Kedelai stelah satu dekade. Majalah tempo.http://majalah.tempoint erakti.com/id/arsip/2010/03/29 /EB/mbm.01.0.id.html. Diases pada tanggal 5 juli 2015 .

Rajiman, 2018. Pengaruh zat pengatur tumbuh (ZPT) Alami terhadap hasil dan kualitas bawang merah, STPP Mangelang Jurusan Penyuluhan pertanian di Yogyakarta.

Saefas, S.A, $d k k$ : Pengaruh kosentrasi zat pengatur tumbuh alami dan sintetik terhadap pertumbuhan tanaman teh (Camellia sinensis (L) O. Kuntze)Klon GMB 7setelah cetering.

Sudaryanto, T dan D,K. Swastika. 2007 Elonomi Kedelai di indonesia . Dalam : kedelai: teknik 
produksi dan penembangan. Sunyamto,

A.Witjono,hermanto, dan $\mathrm{H}$, kasim (Eds). Puslitbangtan, Bogor.

Tarigan, Nurbaiti, Yoseva, S. 2017. Pemberiaan Ekstrak Bawang Merah Sebagai Zat Pengatur Tumbuh Alami Pada Pertumbuhan (Piper nigrum L.) APPLICATION OF ONION EXTRACT AS A NATURAL GROWTH REGULATOR ON PEPPER (Piper nigrum L.). Program
Studi Agroteknologi, Jurusan Agroteknologi Fakultas Pertanian, Universitas Riau. Jom Faperta VOL. 4 NO. 1

Februari 2017

\section{(2015).}

